\title{
The Implementation Of Criminal Law To The Forester Of Land And Land Combustion In Blora Regency
}

\author{
Solikun Ni'am ${ }^{1}$, Akhmad Khisni ${ }^{2}$ and Lathifah Hanim ${ }^{3}$
}

Abstract. The problems discussed in this study are how is the enforcement of criminal law against the perpetrators of forest and land burning in Blora Regency, as well as the factors inhibiting the enforcement of criminal law against perpetrators of forest and land burning in Blora Regency and its solutions. The approach method used is normative juridical, descriptive analytical research specifications. The data used is secondary data. Data collection method is a field study. The data analysis method uses qualitative analysis. As a knife for analysis, law enforcement theory, justice theory and legal certainty theory are used. The results showed that criminal law enforcement against perpetrators of forest and land burning in Blora Regency was not running optimally. This is evidenced by the absence of investigative efforts carried out by PPNS and the National Police in the crime of burning forests and land, so that there has never been a case of forest fires that has been resolved through a criminal route. Law enforcement efforts are preferred through preventive measures. The inhibiting factors of criminal law enforcement against forest and land arsonists in Blora Regency are the factors of laws where there is disharmony of laws governing forest and land burning crimes, difficulties in finding perpetrators and witnesses, limited costs in investigating forest crime and land and lack of public awareness. The solution to overcome these obstacles is to make criminal law the last resort in enforcing forest and land burning laws, not continuing forest fire cases to the investigation stage, and conducting socialization to the public about preventing forest and land burning.

Keywords: Criminal Law Enforcement; Forest And Land Burning.

\section{Introduction}

Forest fires are currently a major problem that must be considered. Historically, forest fires, especially tropical rain forests in Indonesia, have occurred since the 18th century. Fires that occurred in 1877 were known in the forest area between the Katingan and Cempaka rivers (now Sampit and Katingan rivers) in Central Kalimantan Province. ${ }^{4}$ The problem of forest and land fires in Indonesia always repeats as if it were never finished. Basically this is more than the supervision and law enforcement side as an instrument that can be used to cause a deterrent effect. Law enforcement is also part of efforts to prevent the recurrence of fires. In this case the government is still weak in terms of supervision and also law enforcement related to the fire that occurred. From the legal process that has been carried out by itself, there are 11 companies that have

\footnotetext{
${ }^{1}$ Student of Master of Law, Faculty of Law, Sultan Agung Islamic University (UNISSULA) Semarang, email sholikunniam79@gmail.com

${ }^{2}$ Lecturer of Master of Law, Faculty of Law, Sultan Agung Islamic University (UNISSULA) Semarang

${ }^{3}$ Lecturer of Master of Law, Faculty of Law, Sultan Agung Islamic University (UNISSULA) Semarang

${ }^{4}$ Bambang Purbowaseso, 2004, Pengendalian Kebakaran Hutan (Suatu Pengantar), Jakarta: Rineka Cipta, p. 3
} 
inkracht that have been fined Rp.18.9 trillion, but until now there has been no realization, whether they have been fulfilled or not. ${ }^{5}$

Blora Regency is one of the regencies in Central Java Province which has an area of $182,059 \mathrm{Ha}$, most of which is in the form of forests, which is $49 \%$ of the total area. ${ }^{6}$ Blora Regency has the potential for excellence in abundant teak forest resources so that it becomes one of the basic capital to be optimized to become a source of income. The existence of teak forests owned by Blora Regency if maximized will gain economic value through two benefits, namely revenue retribution which will increase local revenue and visits from communities outside the region, both have the opportunity to increase other sectors that can benefit, especially Blora Regency, more broadly for province of Central Java.

The forest area in Blora Regency is prone to fire. For example in August 2019, as many as 50 hectares of forest land in the Cepu Forest Management Unit (KPH) of Blora Regency were burnt. On the same day, there was also a forest fire in an area of approximately 2 ha on the side of the Cepu-Blora KM 7 road in the Sambong subdistrict, which is located in the Kejalen Forest Standing Resort Unit of the Ledok Forest Standing Unit in the Cepu Forest Management Unit. ${ }^{7}$ Most of the causes of forest land fires are due to human neglect such as the disposal of cigarette butts, or the residual burning of sugar cane land that has spread to forest land. There are allegations of tenants who burnt land or corridors. ${ }^{8}$

Based on the description above, the authors are interested in conducting research with the title: "The Implementation Of Criminal Law To The Forester Of Land And Land Combustion In Blora Regency".

Based on the background description described above, the following problems are formulated: How Is Criminal Law Enforcement Against The Perpetrators Of Forest And Land Burning In Blora Regency? What Are The Factors That Impede Criminal Law Enforcement Against Perpetrators Of Forest And Land Burning In Blora Regency And How Is The Solution?

\section{Research Methods}

The method used in this research is normative juridical. The research specification is analytical descriptive, which provides a clear, detailed and systematic picture. The data used are secondary data supported by interviews. The data analysis method uses qualitative analysis.

\section{Results And Discussion}

\footnotetext{
${ }^{5}$ Rizki Akbar Putra, Greenpeace : Pengawasan dan Penegakan Hukum Solusi Kebakaran Hutan dan Lahan di Indonesia, (https://www.dw.com, accessed December 2, 2019).

${ }^{6}$ Andi Setiono, 2011, Ensiklopedi Blora- Alam, Budaya dan Manusia Buku 8 Pertanian, Kehutanan, dan Lingkungan Hidup, Yogyakarta : PT. Nuansa Pilar Media, p. 81.

${ }^{7} 50$ hektar Hutan di KPH Cepu Terbakar, (https://kump.com.com, accessed December 2, 2019).

8 Kebakaran Hutan di Blora Akibat Kelalaian Manusia,, (http://infopublik.id, accessed December 2, 2019).
} 


\subsection{Criminal Law Enforcement of Perpetrators of Forest and Land Burning in Blora Regency}

Blora Regency with an administrative area of $1820.59 \mathrm{~km} 2$ (182058.797 ha), the largest use of its area is as forest which includes state and community forests, which is 49.66\%. Until now the management of the forest area is handled by Perum Perhutani. With an area of almost 50\% forest area, almost every year in the dry season there are always forest fires.

The data collected by the author, throughout 2017 as many as 20 hectares of forest land in Blora Regency were burnt, then in 2018 an increase in the number of forest fires, amounting to 38,175 hectares $^{9}$ and in 2019 there were 150 hectares of forest land that suffered fires, namely each of the 67 hectares Cepu KPH, Randublatung KPH 64 hectares, Blora KPH 6.2 hectares, Mantingan KPH 7.1 hectares and Kebonharjo KPH 63 hectares. $^{10}$

In the Blora Regency area, every dry season there is always a forest fire. This is because a lot of teak leaves that dry fall, as well as thatch and shrubs around the stands of teak trees also dry. When there are people who pass by and throw away cigarette butts whose fire is still burning, then this can cause a fire. This was stated by Kasat Binmas of Blora Regional Police who stated that most of the causes of forest fires in the Blora Regency were people who threw cigarette butts still burning in dry forest areas. In addition, there are also cultivators who burn land or corridors. The long drought also affected the number of forest and land fires in Blora Regency. ${ }^{11}$

The impact of forest fires that occurred in Blora Regency itself was very large, both material and non-material losses. Material losses were particularly experienced by Perhutani due to the large number of teak trees which were burned. While the nonfatal losses experienced by the surrounding community, where community activities are disturbed because of the thick smoke that disturbs the eyes and interferes with breathing. Besides that, the people around the forest who usually look for grass in the forest area for animal feed also experienced difficulties because the grass caught fire. ${ }^{12}$ The National Police as the first level institution in the criminal justice system is the spearhead in criminal law enforcement. In this case the National Police is the frontline or the spearhead in uncovering environmental crime, one of which is the burning of forests and land. Thus, whether or not cases of forest and land burning are revealed depends on the ability and commitment of the investigator.

In the criminal justice system, the police subsystem has preventive and repressive enforcement tasks. Likewise in law enforcement against the crime of burning forests and land. Related to law enforcement against forest burning crime, Kasat Reskrim Blora Police stated that until now Blora Police Station was limited to preventive measures and had never done any specific actions, in the sense that they had never

\footnotetext{
${ }^{9}$ Sepanjang Kemarau tahun ini 38 ha Hutan di Blora Terbakar, (https://news.detik.com, accessed March 1, 2020).

${ }_{10}$ Musim Kemarau 150 Hektar Lahan Jati Di Blora Terbakar, (http://www.rmoljateng.com, accessed March 1, 2020).

${ }^{11}$ Interview with AKP Slamet Iriyanto, Kasat Binmas Blora Police Unit, in Blora, on March 2, 2020.

12 Ibid.
} 
handled the crime of burning forest even though every year there were always forest fires. ${ }^{13}$

Blora Police Station has carried out various activities to control forest fires, namely: ${ }^{14}$

- Campaign to prevent forest and land burning through billboards

- Promoting prevention and handling of forest and land fires

- Routine patrol

- Joint operations in forest areas

Law enforcement of the crime of burning forests and land is carried out through the investigation and investigation stages by the National Police, the prosecution stage by the Prosecutor, and the trial in court by a judge. In the crime of burning forests and land, its relation in the process of investigation and investigation, in addition to Polri officials, other officials who have the authority to conduct investigations are forestry police. This is as regulated in Article 36 paragraph (3) Government Regulation No. 45 of 2004 On Forest Protection which states that forestry police are instructed by the leadership to conduct an investigation, in order to find and arrest suspects.

In the crime of burning forests and land, the investigation can be carried out by PPNS according to the existing law. PPNS can take the same actions as the police in the case of investigations. Since the investigation began, PPNS immediately informed the start of the investigation to the National Police investigator. The notification of the start of this investigation is a form of coordination between civil servant investigators and PPNS investigators. This is done so that after the complete file and investigation results are submitted to the public prosecutor there is no formal error in the case file. ${ }^{15}$

Based on the results of interviews with the Head of Criminal Investigation Unit in Blora, up to now the Blora Regional Police has never carried out an investigation into the crime of burning forest. This is because the Blora Police Station has never received a report from Perhutani regarding the crime of forest and land burning that occurred. In addition, because it is not known the exact cause of the fire, making it difficult to find the perpetrators and find evidence of the crime of forest fires. The efforts made by Blora and Perhutani Resort Police were directed more towards preventive efforts to prevent the burning of forests and land. ${ }^{16}$

During a patrol with Perhutani and a forest fire incident, no fatal forest fires have ever been discovered. However, if there is a forest fire, it will have an impact on the surrounding environment, especially what is felt by the community is smoke that disturbs the view. In the case of a fire in the forest in Blora, the teak tree did not die even though the leaves underneath were burned so that the amount of material loss was not too large. ${ }^{17}$

\footnotetext{
${ }^{13}$ Ibid.

${ }^{14}$ Ibid.

15 The Indonesian Ministry of Environment and Forestry, 2018, Status Hutan dan Kehutanan Indonesia 2018,, Jakarta, Indonesian Ministry of Environment and Forestry, p.52.

${ }^{16}$ The results of an interview with AKP Setiyanto, Kasat Reksrim Polres Blora, in Blora on March 2, 2020.

${ }^{17}$ Ibid.
} 


\subsection{Factors Inhibiting Criminal Law Enforcement of Perpetrators of Forest and Land Burning in Blora Regency and Its Solutions}

Enforcement of criminal law against perpetrators of criminal acts on forest and land burning in Blora Regency cannot run optimally. This is because it prioritizes preemptive efforts rather than repressive efforts. The factors that hinder the enforcement of criminal law against perpetrators of burning and land are as follows:

- Disharmony of laws governing the crime of burning forests and land

Disharmonization of the formulation of articles in the crime of burning forests and land can be seen in Article 69 paragraph (1) letter h of Act No. 32 of 2009 On Environmental Protection and Management which states that everyone is prohibited from clearing land by burning. On the other hand there is an article that allows land burning, namely Article 69 paragraph (2) which states that the provisions as referred to in paragraph (1) letter $h$ take seriously the local wisdom in each area.

Disharmonization of the formulation of articles On criminal acts on forest and land burning is also contained in Article 19 paragraph (1) of Government Regulation Number 45 of 2004 On Forest Protection as amended by Government Regulation Number 60 of 2009 which states that everyone is prohibited from burning forests. However, in the next paragraph it is stated that the exclusion of the prohibition on burning forests as referred to in paragraph (1) is permitted to be done on a limited basis for special purposes or conditions that cannot be avoided. This certainly impedes the criminal law enforcement process against the crime of burning forests in Blora Regency.

In Blora Regency, so far the forest fires have not been fatal. In fact, according to Kasat Reskrim Polres Blora, teak trees will not die even though the shrubs beneath it burn. In addition, after the fire will sprout new plant shoots so that it can be used for animal feed by residents around the forest. ${ }^{18}$

The solution to overcome this is that criminal law enforcement efforts are not carried out in the sense that no investigation of forest and land burning is carried out. In this case criminal law enforcement is an ultimum remedium which is the last resort in law enforcement. Law enforcement officials from the Perhutani and the National Police emphasize local wisdom in enforcing forest and land burning laws in Blora Regency.

- Difficulty looking for perpetrators and witnesses

Based on the results of the Kasat Reskrim Blora Regency Police interview, it shows that although the police have determined to take firm action against the perpetrators of forest and land burning, investigators have so far struggled to find the perpetrators of forest and land burning. This is due to the difficulty of obtaining evidence, as well as witnesses because in the forest / land area there are no

\footnotetext{
18 Interview with AKP Setiyanto, Head of Criminal Investigation Unit at Blora Police Station, in Blora on March 2, 2020.
} 
supporting devices such as CCTV. Moreover, when officers find a forest area that is burning, usually no one is there. ${ }^{19}$

The solution to overcome this obstacle is the non-continuation of cases of forest and land fires to the investigation stage. Without evidence and no perpetrators of forest and land burning crime, investigators cannot continue the investigation process. In addition, the need for enhance the ability of law enforcement officials to identify forest crime offenses through special education and training in the handling of forest and land burning crimes.

- Limited costs in investigating forest and land burning crimes

The process of investigating the crime of burning forests and land requires a very large cost. The results of interviews with the Head of Criminal Investigation Unit of the Blora Regency Police illustrate that the costs for the investigation of forest and land fires are very large while the budget is very limited. In investigating forest and land fire crimes using scientific identification techniques, which must use expert witnesses. To bring in an expert witness, investigators must also finance themselves starting from the cost of transportation, food, lodging, and others. In addition, costs are still needed for laboratory testing and others until the case is submitted to the prosecutor. All these activities can cost a lot of money, while funds are very limited. ${ }^{20}$

The solution to this is an effort to uphold criminal law against the crime of burning forests and land is a last resort and more preventive measures are taken to reduce costs.

- Lack of public awareness

Not all people in Blora Regency have a high level of environmental legal awareness. As it is known that humans always interact with the environment in their lives. If someone do not understand and appreciate the importance of environmental sustainability for survival and life, then a person will tend to be indifferent to the environment, so that he can easily do actions that have a negative impact on the environment, such as throwing out cigarette cigarettes that still have fire in forest areas, opening land by burning which can trigger a fire in the forest area.

The solution to overcome these obstacles is to conduct socialization to the community to instill legal awareness of the environment. The community is given guidance that intentionally or unintentionally burning forests can be subject to criminal or fines. With this activity the community is expected to become aware of the law and participate in preventing forest and land fires.

\section{Closing}

\subsection{Conclusion}

- Criminal law enforcement against forest and land burning perpetrators in Blora Regency is not running optimally. This is evidenced by the absence of investigative

\footnotetext{
${ }^{19}$ Ibid.

${ }^{20}$ Ibid.
} 
efforts carried out by PPNS and the National Police in the crime of burning forests and land, so that there have never been cases of forest fires that have been resolved through the criminal route. Until now law enforcement efforts are prioritized through preventive efforts.

- The inhibiting factors of criminal law enforcement against perpetrators of forest and land burning in Blora Regency are disharmony of laws governing the criminal acts of forest and land burning, difficulty in finding perpetrators and witnesses, limited costs in investigating criminal acts of forest and land burning and lack of public awareness. The solution to overcome these obstacles is to make criminal law the last resort in enforcing forest and land burning laws, not continuing the case of forest fires to the investigation stage, and conducting socialization to the public about preventing forest and land burning.

\subsection{Suggestion}

- For the government, there needs to be a revision of the law governing the crime of forest and land burning so that harmonization between one law and another is related to the formulation of a criminal law on forest and land burning.

- Law enforcement officials need special education and training in investigating the crime of burning forests and land in order to investigate the perpetrators of the crime and provide a deterrent effect for the perpetrators. For the community, it should play an active role in preventing forest and land fires.

\section{Bibliography}

\section{Book}

[1] Andi Setiono, 2011, Ensiklopedi Blora- Alam, Budaya dan Manusia Buku 8 Pertanian, Kehutanan, dan Lingkungan Hidup, Yogyakarta : PT. Nuansa Pilar Media, h. 81.

[2] Bambang Purbowaseso, 2004, Pengendalian Kebakaran Hutan (Suatu Pengantar), Jakarta: Rineka Cipta.

[3] The Indonesian Ministry of Environment and Forestry, 2018, Status Hutan dan Kehutanan Indonesia 2018, Jakarta, the Indonesian Ministry of Environment and Forestry.

\section{Laws and regulations}

[1] Act No. 32 of 2009 On Environmental Protection and Management

[2] Act No. 19 of 2004 On Establishment of Government Regulation in Lieu of Act No. 1 of 2004 On Amendments to Act No. 41 of 1999 On Forestry became Jo Act No. 41 of 1999 On Forestry.

[3] Law of the Republic of Indonesia Number 18 of 2013 On Prevention and Eradication of Forest Destruction.

Etc 
[1] Kebakaran Hutan di Blora Akibat Kelalaian Manusia, (http://infopublik.id, accessed December 2, 2019).

[2] Musim Kemarau 150 Hektar Lahan Jati Di Blora Terbakar, (http://www.rmoljateng.com, accessed March 1, 2020).

[3] Sepanjang Kemarau tahun ini 38 ha Hutan di Blora Terbakar, (https://news.detik.com, accessed March 1, 2020).

[4] Rizki Akbar Putra, Greenpeace : Pengawasan dan Penegakan Hukum Solusi Kebakaran Hutan dan Lahan di Indonesia, (https://www.dw.com, accessed December 2, 2019).

[5] 50 hektar Hutan di KPH Cepu Terbakar, (https://kump.com.com, accessed December 2, 2019). 